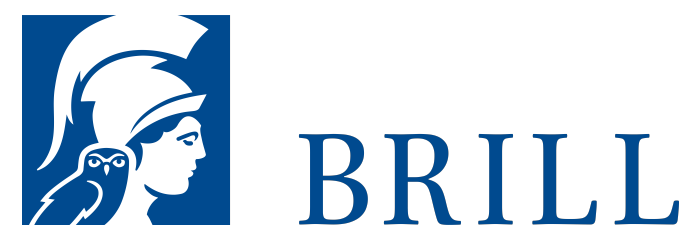

\title{
Philosophie der Religionen
}

Pluralismus und Religionskritik im Kontext europäischen Denkens

\section{Author: Johann Figl}

Angesichts der heutigen weltweiten Vielfalt der Religionen und des Religiösen ist es ein Desiderat gegenwärtiger Tendenzen, in der Religionsphilosophie den konkreten Religionen in ihrer Vielfalt und Unterschiedenheit gerecht zu werden. Von diesem Postulat her ergibt sich, dass eine Religionsphilosophie nur als eine Philosophie der Religionen (im Plural) angemessen ausgearbeitet werden kann.

Da die gegenwärtige Situation der Religionsphilosophie nicht ohne ihre historische Entwicklung zu verstehen ist, wird im vorliegenden Werk zuerst ein Überblick über die abendländischen religionsphilosophischen Reflexionen gegeben, und zwar anhand der leitenden Frage, wie wichtige Positionen europäischen Denkens seit der Antike auf die Pluralität des Religiösen einerseits und auf eine extreme (z. T. atheistische) Religionskritik andererseits geantwortet haben. Vor diesem Hintergrund werden zentrale Perspektiven aktueller Religionsphilosophie (wie die Wahrheitsfrage, interkulturelle Aspekte, religionswissenschaftliche Kontexte) angesichts der heutigen plural-religiösen und weltanschaulichen Situation (einschließlich areligiöser Positionen) thematisiert.

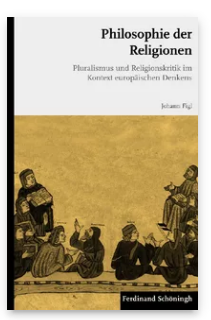

Pages: 308

Seiten

Language:

German

Subjects:

General,

Theology and

World

Christianity

Publisher: Brill |

Schöningh

E-Book (PDF)

Released online:

15 Jul 2019

ISBN: 978-3-

657-72448-2

List price

USD $\$ 63.00$

Paperback

Publication date:

13 Feb 2012

ISBN: 978-3-

506-72448-9

List price

USD $\$ 63.00$ 
Johann Figl, Dr. theol., Dr. phil., ist seit 1986

Universitätsprofessor und Vorstand des Instituts für

Religionswissenschaft an der Kath.-Theol. Fakultät der

Universität Wien.

For more information see brill.com

Order information: Order online at brill.com +44330 3330049 | customerservices@brill.com Submission information: brill.com/authors

Titles published by Brill | Fink, Brill | mentis or Brill | Schöningh: +49(o)71 5413279216 | brill@brocom.de 